DOI 10.18551/rjoas.2019-09.27

\title{
THE ANALYSIS OF RELIGIOUS RELATIONSHIP IN DIVERSITY OF AMARIMA HATUHAHA COMMUNITY
}

\author{
Sahureka Sephliano E.M. \\ Faculty of Christian Education, State Institute of Christian Religion, Ambon, Indonesia \\ E-mail: sephliano1124@gmail.com
}

\begin{abstract}
Amarima Hatuhaha is a group of indigenous people who have special characteristics of history, territory, customs, and language. This community has a kinship relationship since the days of the ancestors. Conflict 1999 damaged the kinship that had been maintained during and raises suspicion that is prolonged in people's lives. The purpose of this research was to analyze the relation of religion in the diversity of the community. To get the data needed, this study used a qualitative method descriptive and done in Maluku. The findings showed that the Hatuhaha Amarima community relations of diversity relations with regard to relational between humans and humans, and the relationship between humans and God, and humans with the universe. The influence of various new religions did not make the change in kinship and brotherhood relations actually makes Hatuhaha Amarima remains in wholeness with a living tradition. The Amarima Hatuhaha community places the values of brotherhood and alliance in order to help each other. The existence of others is guided with use language as a unified using important codes facilitates communication between members of the community.
\end{abstract}

\section{KEY WORDS}

Conflict resolution, women, Ambon, community.

The Amarima Hatuhaha community still maintains noble values existing in culture. Changing times are always accompanied by cultural changes and civilization. Changes in civilization, the development of science and technology, will also affect human behavior, both for nature and fellow human beings (Sztompka, 2008). Peursen Van (1988) emphasized, change epoch accompanied by cultural development generally consists of three the stage of cultural development, namely the mythic stage, the ontology stage, and the stage functional. These stages of cultural development become important to see cultural development in the Hatuhaha Amarima community. Development culture also influences religious behavior and relations. To the community Amarima Hatuhaha, Religious pluralism cannot be avoided, because there are two nature inherent in religion. On one hand, religion has values inclusive, universal and transcending. both religions contain things that are exclusive, particular and primordial (Bahtiar E, 2004).

It is these two faces of religion that cause strong ideals towards religion. Strong and strong idealists can cause conflict between religion. Anticipating conflicts with religious nuances, then theological thinking contextual based on local wisdom can be a reference. Current theological thinking is expected to connect social relations in society and religion. Theological thinking is also expected to regulate the rules related to fellow human beings and relationships with God. Relevant theology in human social life if theology can answer all problems human life. These theological values are laws or rules that are held as the basis of theological teachings, as an expression of belief in God.

Theology itself does not come from the sky or come from somewhere holy but appears in the reality of human life based on social experience. Theological values exist around humans and live in the socio-cultural sphere. In the Amarima society, the theological value is used as an educational tool for the community and resolve conflicts. In the Amarima Hatuhaha community, there is an effort to preserve the noble values. The effort appears from the pattern and understanding of cultural values in people's lives. The purpose of this study analyzes historical, cultural and religious dynamics in the diversity of societies Amarima Hatuhaha. 


\section{METHODS OF RESEARCH}

This research used a descriptive qualitative method. This research conducted in Ambon, Maluku. The location selection was done intentionally. Data collected included primary data and secondary data. Primary data obtained from observation, in-depth interviews and focused group discussions (FGD). Secondary data were obtained from the village office, and previous research reports. The selection of informants was carried out in a purposeful sampling technique. Data analysis technique conducted data collection, data analysis, data reduction, data presentation, and drawing conclusions (Denzin,2009).

\section{RESULTS AND DISCUSSION}

Amarima Hatuhaha is a community group consisting of five countries (Pattikayhatu and Manuputty, 1998). Amarima Hatuhaha community then gather and consult around the mountains of Alaska to form and group themselves in a bond called Amarima Hatuhaha during its development became a political force by establishing "the kingdom of Alaska" (Noya, 1987). Amarima Hatuhaha was formed for the public awareness of the five countries because they have the same fate. The five countries came out of the Nunusaku mountain region on the island of Seram because of this civil war, called the Wemale and Alune wars. The Amarima Hatuhaha group traveled together evacuate, to save themselves from the war of Wemale and Alune. War This has forced the massive migration of the Hatuhaha group Amarima; (Bartels, 1994). It is estimated to occur around the 6th century AD (Rumahuru, 2012). This estimate is based on the arrival of the Chinese people to Maluku 7th century AD, at which time there were already residents on the island of Ambon, Haruku, Saparua, and Nusalaut (Putuhena, 2006). The transition of residence from the mountainous region of Nunusaku on Seram Island to Mount Alaska on Haruku Island, making changes to life patterns and culture. This shows the existence of cultural change and life change sociable. Life changes that occur due to new experiences, knowledge new situation, new situation, and adaptation of way of life to new situation. The community Amarima Hatuhaha lived life in a plurality of beliefs, but still preserving personal characteristics. The community remains in bond as an indigenous community.

The influence of various new religions did not change the kinship and relationship brotherhood, precisely makes Amarima Hatuhah remain in wholeness with living traditions (culture and customs) that remain strong. Community integrity continues to occur although Islam is embraced by the four countries (Pelauw, Rohomoni, Kabau, and Kailolo) and Christians are adopted by the land of Hulaliu. Islam and Christianity do not eliminate Amarima Hatuhaha's ties to culture and tradition. Various rituals are always held routinely for the process of cultural preservation such as hot rites and heat (Watloly, 2012). Amarima Hatuhaha's social order can be seen in traditional activities, culture, and religion, as well as non-relations other formal. These cultural values strengthen social relations and work with Amarima Hatuhaha (Bartels, 1978).

The Amarima Hatuhaha community is the name of a traditional country that has history, culture, language, and ethnicity. Before the entry of the major religions, like Islam and Christianity. These people have embraced the "authentic religion" belief of Hatuhaha. Their native religion is professed because of emotions and a sense of unity that has the same sense of fate. Sometime later, the "original religion" belief of Hatuhaha was abandoned and replaced by belief Islam. The entry of the Portuguese and followed by the arrival of the Dutch, after defeating the Portuguese, made the people of Amarima Hatuhaha are in a different religion because the Hulaliu country finally embraced religion Christian. Islam and Christianity are located and developing in the middle Amarima Hatuhaha's alliance. As an indigenous people and country, Hulaliu country cannot be ostracised and ignored, let alone excluded from membership in the partnership which was built by the ancestors.

Likewise, as a community of faith (religion), the Christian Hulaliu community was accepted sincerely by other brothers, even they are not forced to leave the trust Christianity and return to Islam, or vice versa countries that are Muslims renounce their beliefs and 
embrace Christianity. Religion that exists in the unity of Amarima Hatuhaha who has lived and developing not only within the entire territory of the Haruku island but also in a manner specified in the unitary area of Amarima Hatuhaha land. This awareness makes Christianity remains freely developed, the gospel is transparently preached on in the midst of the unity of the community. Christianity is placed in a manner proportional. Its main role is in a traditional practice. There are two reasons community Amarima Hatuhaha accept Christianity. First, the existence of the gospel as the Strength and salvation of God. Secondly, the spirit to leave you his brother, for the safety and wholeness of his other brothers. The development of religions in the unity of Hatuhaha Amarima is getting more and more present experience differences, not only in the form of religious institutions but also in form of perspective that influences the behavior of every religious community. The development of religions shows that the religiosity of the Amarima community Hatuhaha always shows a dynamic situation. Religious dynamics which directly makes the Amarima Hatuhaha community in a plural state. Pluralism is not only in terms of religion, but also appears in the flow- a developing flow and a different perspective on religion.

Differences in this perspective also affect people's behavior towards a circumstance or the surrounding context. Likewise with those who follow the religion of Islam. The results of observations note that there are two models of religious procedures within Amarima Hatuhaha community who are Muslim, first, Model traditional, second, modern model. Both of these models are in a situation where each wants to maintain an Islamic identity according to the point of view. The Hatuhaha Amarima community lives a pluralistic life faith, but still preserving their personal characteristics. The community remains in bond as an indigenous group. Various factors have influenced the new religion and therefore it does not change the relationship between kinship and brotherhood, it makes Hatuhaha Amarima remain in complete integrity with living traditions (culture and customs) that remain strong. Community integrity continues to occur through Islam was adopted by the four countries (Pelauw, Rohomoni, Kabau, and Kailolo) and Christianity was adopted by the land of Hulaliu. Islam and Christianity do not eliminate Hatuhaha Amarima's ties to culture and tradition. The community Hatuhaha Amarima still maintains the noble values that are in Hatuhaha culture.

Amarima Hatuhaha community formed from the period before the colonialism until now it has not abandoned indigenous customs, traditions, and culture. Local language, including the language Hatuhaha, indeed had been banned from using it in Christianity since the Dutch era, but apparently, until now the people of Hulaliu still continue to use it (Cooley, 1987). One of the uniqueness and identity of the unity the Amarima community is the language that has become a symbol and tools that unite the community. Language at the level Human communication always uses verbal symbols with certain regularities which is organized in "sociology-linguistic codes". Amarima Hatuhaha community use important codes to facilitate communication between members of the community. The code is used to open an ongoing communication or open a conversation. The code also serves to introduce identity as a member of Amarima Hatuhaha, introducing social status in the unity community. Traditionally, communication is in the Amarima community is known by the first three forms of Pasawari, namely human communication with the ruler in the sky (God) realized by praying. Communication with a ruler in the sky using Hatuhaha language. both Palamana or Patamasi is human communication with humans in a day's activity as well as in traditional activities. The third Pataniti is communication with spirits. This is also done if personal or group life is threatened. The communication also uses Hatuhaha. Existence and interaction the land of Hulaliu as a Christian country in the midst of the four Islamic countries seem to be inseparable from the course of history in the Amarima alliance Hatuhaha. The life of indigenous groups who have cultural strength needs to be a concern, so it must be known the depth of socio-its culture (Liliweri, 2001). According to Uhi (2005) the religious life of the people of Hatuhaha Amarima as a place to build contextual pluralistic theology. Awareness of new civilizations occurred when attention and consideration to return to traditional forms of social life abandoned or destroyed by modernization seen in post-modern times, which will show consideration for rebuilding the community, reuse of primordial social ties, revive groups and primary relationship (Sztompka, 2008). 


\section{CONCLUSION}

In the Hatuhaha Amarima community, the relation of diverse relationships is related to the relationship between humans and humans, and the relationship between humans and God and man with the universe. The influence of various new religions does not make the change in kinship and brotherhood relations. Actually this makes Hatuhaha Amarima remaining in wholeness with living traditions (culture and customs) that stays firm. The community places the values of brotherhood and fellowship in order to help each other help. The existence of others is maintained by using language as a unifier. The Amarima Hatuhaha community uses important codes to facilitate communication between members of the community.. This community places the values of brotherhood and fellowship in order to enliven each other and help one another.

\section{REFERENCES}

1. Bartels, Dieter,1978, Guarding The Invisible Mountain: Intervillage Alliances, Religious Syncretism and Ethnic Identity Among Ambonese Christians and Moslems in The Mollucas, University Microfilms Internartional, London.

2. Cooley, Frank L, 1987, Mimbar and Tahta: Hubungan Lembaga-Lembaga Keagamaan and Pemerintahan di Maluku Tengah, Pustaka Sinar Harapan, Jakarta.

3. Denzin, Norman K. and Lincoln, Yvonna S, 2009, Handbook of Qualitative Research,

4. diterjemahkan oleh Dariyatno dkk, Pustaka Pelajar, Yogyakarta.

5. Liliweri, A. 2001, Gatra-Gatra Komunikasi Antarbudaya, Pustaka Pelajar,Yogyakarta.

6. Liliweri,A. 2009, Prasangka and Konflik: Komunikasi Lintas Budaya Masyarakat Multikultur, LKis, Yogyakarta.

7. Noya, Matheus, 1987, "Hatuhaha Dahulu and Sekarang: Studi tentang Perubahan Organisasi Kemasyarakatan di Negeri Hulaliu", Skripsi, Fakultas Keguruan and IImu Pendidikan Universitas Pattimura, Ambon.

8. Pattikayhatu, J.A., and Manuputty, M., 1998, Sejarah Lokal Maluku: Uli Hatuhaha, Departemen Pendidikan and Kebudayaan, Dirjen Kebudayaan Direktorat Sejarah and Nilai Tradisional, Proyek Inventarisasi and Dokumentasi Sejarah Nasional, Ambon.

9. Peursen, C. A. van, 2003, Menjadi Filsuf: Suatu Pendorong ke Arah Berfilsafat Sendiri, diterjemahkan oleh Fitra Salam, dari buku "Wegwijs in de Wijsbegeerte: Een Aansporing tot Zelf Filosoferen", CV. Qalam, Yogyakarta.

10. Peursen, C. A. 1987, "Gospel and Culture: Experience and Conceptualization",dalam The Ecumenical Review, Index Vol. 39, World Council of Churches.

11. Putuhena, M. Shaleh, 2006, "Interaksi Islam and Budaya di Maluku: Perspektif Historis and Religio-Politik", dalam Menjadi Indonesia: 13 Abad Eksistensi Islam di Bumi Nusantara, editor: Komarudin Hidayat and Ahmad Gaus AF, Kerja sama Penerbit Mizan and Yayasan Festival Istiqlal, Jakarta.

12. Rumahuru, Yance Zadrak, 2010, "Dinamika Identitas Komunitas Muslim Hatuhaha di Pulau Haruku, Maluku Tengah", dalam Jurnal Masyarakat Indonesia, Majalah IImu-IImu Sosial, edisi XXXVI, No. 1, Lembaga Ilmu Pengetahuan Indonesia, Jakarta.

13. Rumahuru,2012, "Islam Syariah and Islam Adat: Konstruksi Identitas Keagamaan and Perubahan Sosial di Kalangan Komunitas Muslim Hatuhaha di Negeri Pelauw", Disertasi, Sekolah Pascasarjana Universitas Gadjah Mada, Yogyakarta.

14. Sztompka, P., 2008, Sosiologi Perubahan Sosial, Diindonesiakan oleh Alimandan, Prenada, Jakarta.

15. Uhi, Jannes A., 2011a, "Budaya Pela Maluku dalam Kajian Filsafat Kebudayaan: Implikasinya bagi Nasionalisme Indonesia", dalam Sepotong Tradisi, Seuntai Makna: Sebuah Usaha Menggali Filsafat Nusantara, Editor: Ibrahim and Jannes A. Uhi, Khomsa, Yogyakarta.

16. Watloly, Aholiab, 2012, "Memperkuat Falsafah Hidop Orang Basudara", dalam Berlayar dalam Ombak Berkarya bagi Negeri: Pemikiran Anak Negeri untuk Mollucas, (buku Karel Albert Ralahalu), editor: Abidin Wakano dkk, Ralahalu Institut, Ambon. 